\title{
ANTARA EYD DAN PUEBI: SUATU ANALISIS KOMPARATIF
}

\author{
Zetty Karyati \\ Program Studi Teknik Informatika, Universitas Indraprasta PGRI \\ Email: zettyagung@yahoo.com
}

\begin{abstract}
Abstrak
Ejaan merupakan satu aspek yang penting dalam penggunaan bahasa Indonesia yang benar. Dalam sejarah perkembangan bahasa Indonesia telah terjadi beberapa kali perubahan aturan ejaan. Dua yang terakhir ialah yang disebut Ejaan yang Disempurnakan (EYD) dan Pedoman Umum Ejaan Bahasa Indonesia (PUEBI). Penelitian ini bertujuan untuk membandingkan antara EYD dan PUEBI. Metode penelitian yang digunakan ialah metode kepustakaan untuk mendapatkan analisis komparatif. Dari perbandingan dua ejaan mutakhir ini didapat hasil bahwa antara EYD dan PUEBI terdapat banyak sekali perubahan. Perubahan itu bisa berupa penambahan, penghilangan, pengubahan, dan pemindahan klausul.
\end{abstract}

Kata Kunci: Ejaan, EYD, PUEBI.

\section{Pendahuluan}

Di dalam sejarah perkembangan bahasa Indonesia, terjadi beberapa kali perubahan ejaan. Ejaan di Indonesia diawali dengan Ejaan Van Ophuijsen (1901). Pada 19 Maret 1947, Ejaan Van Ophuijsen digantikan dengan Ejaan Soewandi/Republik. Pada akhir 1959, dirumuskan Ejaan Melayu-Indonesia (Melindo). Namun, ejaan itu tidak sempat diresmikan oleh pemerintah karena keadaan politik di Indonesia yang sedang kacau. Kemudian, pada 16 Agustus 1972, berlakulah Ejaan yang Disempurnakan (EYD) berdasarkan Keputusan Presiden No. 57.Tahun 1972.

Sesuai dengan namanya, EYD beberapa kali mengalami penyempurnaan. Pada tahun 1987, Menteri Pendidikan dan Kebudayaan Republik Indonesia mengeluarkan Keputusan Menteri No. 054a/U/1987 tentang Penyempurnaan "Pedoman Umum Ejaan Bahasa Indonesia yang Disempurnakan". Selain itu, Menteri Pendidikan Nasional juga mengeluarkan Peraturan Menteri Pendidikan Nasional Nomor 46 Tahun 2009 tentang "Pedoman Umum Ejaan Bahasa Indonesia yang Disempurnakan".

Selanjutnya, pada 26 November 2015 lalu, Menteri Pendidikan dan Kebudayaan RI, Anies Baswedan, menetapkan Peraturan Menteri Pendidikan dan Kebudayaan RI No. 50 Tahun 2015 tentang Pedoman Umum Ejaan Bahasa Indonesia. Berdasarkan ketetapan tersebut, Badan Pengembangan dan Pembinaan Bahasa Indonesia merilis Pedoman Umum Ejaan Bahasa Indonesia (PUEBI) sebagai pengganti EYD. Dengan disahkannya ketetapan itu, nama ejaan yang berlaku di Indonesia bukan lagi EYD, melainkan PUEBI. Perubahan nama EYD menjadi PUEBI ini, menurut Kepala Bidang Pemasyarakat Badan Pengembangan dan Pembinaan Bahasa Indonesia, Drs. Mustakim, M.Hum., dilakukan karena banyaknya kritik yang muncul dari masyarakat mengenai nama EYD.

Ada beberapa hal yang melatarbelakangi perubahan ejaan bahasa Indonesia ini. Pertama, dampak kemajuan ilmu pengetahuan, teknologi, dan seni yang telah menyebabkan penggunaan bahasa Indonesia dalam berbagai ranah pemakaian, baik secara tulis maupun tulisan, menjadi semakin luas. Hal ini membuat diperlukannya perubahan pada ejaan bahasa Indonesia. Kedua, perlunya menyempurnakan PUEBI untuk memantapkan fungsi bahasa Indonesia sebagai bahasa negara juga menjadi alasan dilakukannya perubahan.

Namun, perubahan atau perkembangan ejaan yang berlaku di Indonesia ini jarang sekali disosialisasikan oleh Badan Pengembangan dan Pembinaan Bahasa Indonesia. Karena itu, 
masyarakat pengguna bahasa sering kali tidak mengetahuinya, padahal sosialisasi ini tentu menjadi hal yang teramat penting karena pemahaman akan ejaan merupakan satu aspek yang penting dalam mendukung penggunaan bahasa Indonesia yang benar, terutama dalam hal penulisan karya ilmiah dan tulisan formal lainnya. Untuk itulah, penelitian ini dilakukan. Selain untuk memperoleh perbandingan antara EYD dan PUEBI, makalah ini sekaligus juga diharapkan dapat menyosialisasi Pedoman Umum Ejaan Bahasa Indonesia.

\section{Tinjauan Pustaka}

Dalam Kamus Besar Bahasa Indonesia (2010) dinyatakan bahwa ejaan adalah kaidah-kaidah cara menggambarkan bunyi-bunyi dalam bentuk huruf serta penggunaan tanda baca dalam tataran wacana. Adapun menurut "Kamus Besar Bahasa Indonesia IV Daring" (2016), ejaan adalah kaidah cara menggambarkan bunyi (kata, kalimat, dsb.) dalam bentuk tulisan (hurufhuruf) serta penggunaan tanda baca.

Senada dengan definisi-definisi tersebut, menurut Alex dan Achmad (2010), ejaan adalah keseluruhan peraturan melambangkan bunyi ujaran, pemisahan dan penggabungan kata, penulisan kata, huruf, dan tanda baca. Adapun menurut Wijayanti (2013), ejaan adalah kaidah cara menggambarkan/melambangkan bunyi-bunyi ujaran (kata, kalimat, dan sebagainya) dan bagaimana hubungan antara lambang-lambang itu (pemisahan dan penggabungannya dalam suatu bahasa). Jadi, yang dimaksud dengan ejaan adalah keseluruhan peraturan pelambangan bunyi ujaran, penggabungan atau pemisahan kata, penulisan kata, penggunaan lambang bilangan, dan pemakaian tanda baca.

Pengertian kata ejaan berbeda dari mengeja. Mengeja adalah kegiatan melafalkan huruf, suku kata atau kata; sedangkan ejaan adalah suatu sistem aturan yang jauh lebih luas dari sekadar masalah pelafalan. Ejaan mengatur keseluruhan cara menuliskan bahasa dengan menuliskan huruf, kata, dan tanda baca sebagai sarananya. Ejaan merupakan kaidah yang harus dipatuhi oleh pemakai bahasa demi keteraturan dan keseragaman bentuk, terutama dalam bahasa tulis. Keteraturan bentuk akan berimplikasi pada ketepatan dan kejelasan makna.

Berdasarkan konsepsi ejaan tersebut, cakupan bahasan ejaan meliputi (1) pemakaian huruf vokal dan konsonan, huruf kapital dan kursif, (2) penulisan dan bentukan kata, (3) penulisan unsur serapan, afiksasi, dan kata asing, dan (4) penempatan dan pemakaian tanda baca. Semua aspek tersebut ditata dalam kaidah ejaan yang disebut Ejaan Bahasa Indonesia yang Disempurnakan (EYD) sejak tahun 1972.

\section{Metodologi Penelitian}

Penelitian ini dilakukan dengan metode kepustakaan dan metode komparatif. Tujuan dari penelitian komparatif ialah untuk menemukan persamaan-persamaan dan/atau perbedaanperbedaan dari dua(atau lebih) objek. Penelitian seperti ini bisa juga dilakukan pada sebuah objek, tetapi dalam kurun waktu berbeda. Adapun, seperti telah disebutkan di atas, objek yang akan dianalisis dalam penelitian ini ialah Pedoman Umum Ejaan Bahasa Indonesia yang Disempurnakan dan Pedoman Umum Ejaan Bahasa Indonesia.

\section{Hasil dan Pembahasan}

Setelah membaca, menganalisis, dan membandingkan kedua lampiran peraturan menteri tersebut, ditemukan banyak sekali perubahan. Adapun butir-butir perubahan dariPedoman Umum EYD (lampiran Permendiknas RI No. 46 Tahun 2009) ke PUEBI (lampiran Permendikbud RI No. 50 Tahun 2015) ialah sebagai berikut.

1. Pada PUEBI halaman 5-6 diberi penambahan informasi pelafalan penggunaan diakritik é dan è, seperti dapat dilihat pada bagian keterangan di bawah ini. 
Keterangan:

* Untuk pengucapan (pelafalan) kata yang benar, diakritik berikut ini dapat digunakan jika ejaan kata itu dapat menimbulkan keraguan.

a. Diakritik (é) dilafalkan [e].

Misalnya:

Anak-anak bermain di teras (téras).

Kedelai merupakan bahan pokok kecap (kécap).

b. Diakritik (è) dilafalkan $[\varepsilon]$.

Misalnya:

Kami menonton film seri (sèri).

Pertahanan militer (militèr) Indonesia cukup kuat.

c. Diakritik (ê) dilafalkan [ə].

Misalnya:

Pertandingan itu berakhir seri (sêri).

Upacara itu dihadiri pejabat teras (têras) Bank Indonesia.

Kecap (kêcap) dulu makanan itu.

2. Pada bagian keterangan mengenai "Huruf Konsonan" terdapat dua perbedaan, yaitu

a. Penghilangan keterangan: * Huruf $k$ di sini melambangkan bunyi hamzah.

b. Penambahan keterangan: Huruf $x$ pada posisi awal kata diucapkan [s].

3. Pada EYD, hanya terdapat tiga diftong (ai, au, dan oi), sedangkan pada PEUBI terdapat empat diftong (ai, au, ei, dan oi). Berarti, ada penambahan diftong "ei", misalnya pada kata "survei".

4. Catatan pada bagian "Gabungan Huruf Konsonan" EYD yang menyatakan bahwa "Nama orang, badan hukum, dan nama diri yang lain ditulis sesuai dengan Ejaan Bahasa Indonesia yang Disempurnakan, kecuali jika ada pertimbangan khusus" dihilangkan.

5. Pada bagian penulisan "Huruf Kapital" terdapat enam perbedaan, yaitu:

a. Penambahan penjelasan unsur nama orang, yaitu yang termasuk julukan ditulis dengan huruf kapital, misalnya: Jenderal Kancil dan Dewa Pedang.

b. Penambahan penjelasan unsur nama orang yang bermakna 'anak dari' (seperti bin, binti, boru, dan van) tidak ditulis dengan huruf kapital.

Catatan:

1) Huruf kapital tidak dipakai sebagai huruf pertama nama orang yang merupakan nama jenis atau satuan ukuran.

Misalnya:

ikan mujair

mesin diesel

5 ampere

10 volt

2) Huruf kapital tidak dipakai untuk menuliskan huruf pertama kata yang bermakna 'anak dari', seperti bin, binti, boru, dan van, atau huruf pertama kata tugas.

Misalnya:

Abdul Rahman bin Zaini

Siti Fatimah binti Salim

Indani boru Sitanggang

Charles Adriaan van Ophuijsen

Ayam Jantan dari Timur

Mutiara dari Selatan 
c. Penambahan cara pembedaan unsur nama geografi yang menjadi bagian nama diri dan nama jenis. Seperti terlihat pada kutipan berikut:

Nama yang disertai nama geografi dan merupakan nama jenis dapat dikontraskan atau disejajarkan dengan nama jenis lain dalam kelompoknya.

Misalnya:

Kita mengenal berbagai macam gula, seperti gula jawa, gula pasir, gula tebu, gula aren, dan gula anggur.

Kunci inggris, kunci tolak, dan kunci ring mempunyai fungsi yang berbeda. Contoh berikut bukan nama jenis.

Dia mengoleksi batik Cirebon, batik Pekalongan, batik Solo, batik Yogyakarta, dan batik Madura.

Selain film Hongkong, juga akan diputar film India, film Korea, dan film Jepang.

Murid-murid sekolah dasar itu menampilkan tarian Sumatra Selatan, tarian Kalimantan Timur, dan tarian Sulawesi Selatan.

d. Penambahan contoh gelar lokal, seperti terlihat pada kutipan di bawah ini.

K.H. kiai haji

$H j$. hajah

Mgr. monseigneur

$P d t$. pendeta

$D g$. daeng

Dt. datuk

R.A. raden ayu

St. sutan

Tb. tubagus

Dr. doktor

Prof. profesor

Tn. tuan

$N y$. nyonya

Sdr. Saudara

e. Penambahan penjelasan penulisan kata atau ungkapan lain yang digunakan sebagai penyapaan ditulis dengan huruf kapital, misalnya: "Hai, Kutu Buku, sedang menulis apa?"

f. Penghilangan klausul "Huruf kapital dipakai sebagai huruf pertama pada kata, seperti keterangan, catatan, dan misalnya yang didahului oleh pernyataan lengkap dan diikuti oleh paparan yang berkaitan dengan pernyataan lengkap itu.

6. Pada bagian penulisan "Huruf Miring" terdapat tiga perbedaan, yaitu:

a. Perubahan "bukan bahasa Indonesia" menjadi "dalam bahasa daerah atau bahasa asing" ditulis dengan huruf miring.

Huruf miring dipakai untuk menuliskan kata atau ungkapan dalam bahasa daerah atau bahasa asing.

Misalnya:

Upacara peusijuek (tepung tawar) menarik perhatian wisatawan asing yang berkunjung ke Aceh.

Nama ilmiah buah manggis ialah Garcinia mangostana.

Weltanschauung bermakna 'pandangan dunia'.

Ungkapan bhinneka tunggal ika dijadikan semboyan negara Indonesia.

b. Penambahan catatan bahwa nama diri dalam bahasa daerah atau bahasa asing tidak perlu ditulis dengan huruf miring.

Catatan:

1) Nama diri, seperti nama orang, lembaga, atau organisasi, dalam bahasa asing atau bahasa daerah tidak ditulis dengan huruf miring. 
2) Dalam naskah tulisan tangan atau mesin tik (bukan komputer), bagian yang akan dicetak miring ditandai dengan garis bawah.

3) Kalimat atau teks berbahasa asing atau berbahasa daerah yang dikutip secara langsung dalam teks berbahasa Indonesia ditulis dengan huruf miring.

c. Penghilangan bagian 3c, yaitu klausul "Ungkapan asing yang telah diserap ke dalam bahasa Indonesia penulisannya diperlakukan sebagai kata Indonesia.

Misalnya:

Negara itu telah mengalami empat kali kudeta.

Korps diplomatik memperoleh perlakuan khusus.

7. Pada bagian penulisan "Huruf Tebal" terdapat empat perbedaan, yaitu sebagai berikut.

a. Penghilangan klausul bahwa bukan huruf tebal yang dipakai untuk menegaskan, melainkan huruf miring.

b. Penghilangan klausul penggunaan huruf tebal dalam kamus.

c. Penambahan klausul "Huruf tebal dipakai untuk menegaskan bagian tulisan yang sudah ditulis dengan huruf miring".

Misalnya:

Huruf $d h$, seperti pada kata Ramadhan, tidak terdapat dalam Ejaan Bahasa Indonesia yang Disempurnakan.

Kata et dalam ungkapan ora et labora berarti 'dan'

d. Penambahan contoh bagian karangan yang ditulis dengan huruf tebal.

Misalnya:

\subsection{Latar Belakang dan Masalah}

Kondisi kebahasaan di Indonesia yang diwarnai oleh satu bahasa standar dan ratusan bahasa daerah-ditambah beberapa bahasa asing, terutama bahasa Inggrismembutuhkan penanganan yang tepat dalam perencanaan bahasa. Agar lebih jelas, latar belakang dan masalah akan diuraikan secara terpisah seperti tampak pada paparan berikut.

\subsubsection{Latar Belakang}

Masyarakat Indonesia yang heterogen menyebabkan munculnya sikap yang beragam terhadap penggunaan bahasa yang ada di Indonesia, yaitu (1) sangat bangga terhadap bahasa asing, (2) sangat bangga terhadap bahasa daerah, dan (3) sangat bangga terhadap bahasa Indonesia.

\subsubsection{Masalah}

Penelitian ini hanya membatasi masalah pada sikap bahasa masyarakat Kalimantan terhadap ketiga bahasa yang ada di Indonesia. Sikap masyarakat tersebut akan digunakan sebagai formulasi kebijakan perencanaan bahasa yang diambil.

\subsection{Tujuan}

Penelitian ini bertujuan untuk mengetahui dan mengukur sikap bahasa masyarakat Kalimantan, khususnya yang tinggal di kota besar terhadap bahasa Indonesia, bahasa daerah, dan bahasa asing.

8. Pada bagian penulisan kata, terdapat enam perubahan, yaitu

a. Penambahan catatan pada butir B1.

Catatan:

Imbuhan yang diserap dari unsur asing, seperti -isme, -man, -wan, atau -wi, ditulis serangkai dengan bentuk dasarnya.

Misalnya:

sukuisme

seniman

kamerawan

gerejawi 
b. Penghilangan bagian B.1.b, yaitu klausul "Imbuhan dirangkaikan dengan tanda hubung jika ditambahkan pada bentuk singkatan atau kata dasar yang bukan bahasa Indonesia.

Misalnya:

mem-PHK-kan

di-PTUN-kan

di-upgrade

me-recall"

c. Pemindahan bagian B.2. yaitu klausul "Jika bentuk dasarnya berupa gabungan kata, awalan atau akhiran ditulis serangkai dengan kata yang langsung mengikuti atau mendahuluinya" ke bagian D.3. (Gabungan Kata).

d. Pemindahan bagian B.3. yaitu klausul "Jika bentuk dasar yang berupa gabungan kata mendapat awalan dan akhiran sekaligus, unsur gabungan kata itu ditulis serangkai" ke bagian D.4. (Gabungan Kata).

e. Penghilangan klausul "Bentuk-bentuk terikat dari bahasa asing yang diserap ke dalam bahasa Indonesia, seperti pro, kontra, dan anti, dapat digunakan sebagai bentuk dasar.

Misalnya:

Sikap masyarakat yang pro lebih banyak daripada yang kontra.

Mereka memperlihatkan sikap anti terhadap kejahatan."

f. Penghilangan klausul "Kata tak sebagai unsur gabungan dalam peristilahan ditulis serangkai denganbentuk dasar yang mengikutinya, tetapi ditulis terpisah jika diikuti oleh bentuk berimbuhan.

Misalnya:

taklaik terbang

taktembus cahaya

tak bersuara

tak terpisahkan"

9. Penambahan klausul "Singkatan nama diri dan gelar yang terdiri atas dua huruf atau lebih tidak dipenggal". Selain itu juga ditambahkan contoh dan catatan.

Misalnya:

Ia bekerja di DLLAJR.

Pujangga terakhir Keraton Surakarta bergelar R.Ng. Rangga Warsita.

Catatan:

Penulisan berikut dihindari.

Ia bekerja di DLL-

AJR.

Pujangga terakhir Keraton Surakarta bergelar R.

Ng. Rangga Warsita.

10. Pada Bag II.F. terdapat perubahan judul. Jika pada EYD, judul pada bagian ini ialah "Kata Depan di, ke, dan dari", pada PUEBI judulnya diubah menjadi "Kata Depan"

Seperti terlihat pada PUEBI berikut ini:

\section{F. Kata Depan}

Kata depan, seperti $d i, k e$, dan dari, ditulis terpisah dari kata yang mengikutinya.

Misalnya:

Di mana dia sekarang?

Kain itu disimpan di dalam lemari.

Dia ikut terjun ke tengah kancah perjuangan.

Mari kita berangkat ke kantor.

Saya pergi ke sana mencarinya.

Ia berasal dari Pulau Penyengat.

Cincin itu terbuat dari emas. 
11. Penambahan keterangan "Partikel pun yang merupakan unsur kata penghubung ditulis serangkai" dan dilengkapi pula dengan contoh pemakaiannya dalam kalimat, seperti berikut ini.

Misalnya:

Meskipun sibuk, dia dapat menyelesaikan tugas tepat pada waktunya.

Dia tetap bersemangat walaupun lelah.

Adapun penyebab kemacetan itu belum diketahui.

Bagaimanapun pekerjaan itu harus selesai minggu depan.

12. Pada bagian "Angka dan Bilangan" terdapat penambahan klausul "Bilangan yang digunakan sebagai unsur nama geografi ditulis dengan huruf", seperti terlihat pada contoh di bawah ini.

Bilangan yang digunakan sebagai unsur nama geografi ditulis dengan

huruf.

Misalnya:

Kelapadua

Kotonanampek

Rajaampat

Simpanglima

Tigaraksa

13. Penghilangan klausul "Kata ganti itu (-ku, -mu, dan -nya) dirangkaikan dengan tanda hubung apabila digabung dengan bentuk yang berupa singkatan atau kata yang diawali dengan huruf kapital".

14. Pada bagian pemakaian tanda baca "Tanda Hubung" terdapat tiga perbedaan, yaitu sebagai berikut.

a. Penambahan klausul penggunaan tanda hubung antara (1) kata dengan kata ganti Tuhan, (2) huruf dan angka, dan (3) kata ganti dengan singkatan.

Tanda hubung dipakai untuk merangkai

1) $s e$ - dengan kata berikutnya yang dimulai dengan huruf kapital (se-Indonesia, $s e-$ Jawa Barat);

2) ke- dengan angka (peringkat $k e-2)$;

3) angka dengan - an (tahun 1950-an);

4) kata atau imbuhan dengan singkatan yang berupa huruf kapital (hari- $H$, sinar- $X$, ber-KTP, di-SK-kan);

5) kata dengan kata ganti Tuhan (ciptaan- $N y a$, atas rahmat- $M u$ );

6) huruf dan angka (D-3, S-1, S-2); dan

7) kata ganti $-k u,-m u$, dan -nya dengan singkatan yang berupa huruf kapital (KTP$m u$, SIM-nya, STNK-ku).

Catatan:

Tanda hubung tidak dipakai di antara huruf dan angka jika angka tersebut melambangkan jumlah huruf.

Misalnya:

BNP2TKI (Badan Nasional Penempatan dan Perlindungan Tenaga Kerja Indonesia)

LP3I (Lembaga Pendidikan dan Pengembangan Profesi Indonesia)

P3K (pertolongan pertama pada kecelakaan)

b. Perubahan klausul "Tanda hubung- dipakai untuk merangkai unsur bahasa Indonesia dengan unsur bahasa daerah atau bahasa asing" dari hanya "bahasa asing" pada EYD. 
Tanda hubung dipakai untuk merangkai unsur bahasa Indonesia dengan unsur bahasa daerah atau bahasa asing.

Misalnya:

di-sowan-i (bahasa Jawa,_didatangi ${ }^{*}$ )

ber-pariban (bahasa Batak, _bersaudara sepupu')

di-back up

me-recall

pen-tackle-an

c. Penambahan klausul "Tanda hubung digunakan untuk menandai bentuk terikat yang menjadi objek bahasan.

Tanda hubung digunakan untuk menandai bentuk terikat yang menjadi objek bahasan.

Misalnya:

Kata pasca- berasal dari bahasa Sanskerta.

Akhiran -isasi pada kata betonisasi sebaiknya diubah menjadi pembetonan.

15. Pada bagian pemakaian tanda petik terdapat penambahan klausul "Tanda petik dipakai untuk mengapit judul sajak, lagu, film, sinetron, artikel, naskah, atau bab buku yang dipakai dalam kalimat".

Misalnya:

Sajak "Pahlawanku" terdapat pada halaman 125 buku itu.

Marilah kita menyanyikan lagu "Maju Tak Gentar"!

Film "Ainun dan Habibie" merupakan kisah nyata yang diangkat dari sebuah novel.

Saya sedang membaca "Peningkatan Mutu Daya Ungkap Bahasa Indonesia" dalam buku Bahasa Indonesia Menuju Masyarakat Madani.

Makalah "Pembentukan Insan Cerdas Kompetitif" menarik perhatian peserta seminar.

Perhatikan "Pemakaian Tanda Baca" dalam buku Pedoman Umum Ejaan Bahasa Indonesia yang Disempurnakan."

16. Perubahan klausul "Tanda kurung mengapit angka atau huruf yang memerinci satu urutan keterangan" menjadi "Tanda kurung dipakai untuk mengapit huruf atau angka yang digunakan sebagai penanda pemerincian". Kemudian, dilanjutkan dengan pemberian contoh:

Misalnya:

Faktor produksi menyangkut (a) bahan baku, (b) biaya produksi, dan (c) tenaga kerja.

Dia harus melengkapi berkas lamarannya dengan melampirkan

(1) akta kelahiran,

(2) ijazah terakhir, dan

(3) surat keterangan kesehatan

17. Pada EYD, penggunaan garis miring (/) hanya terdapat 2 butir, sedangkan pada PUEBI ada tiga butir, Penambahan klausul pada pemakaian garis miring miring pada PUEBI ialah "Tanda garis miring dipakai untuk mengapit huruf, kata, atau kelompok kata sebagai koreksi atau pengurangan atas kesalahan atau kelebihan di dalam naskah asli yang ditulis orang lain”. Selain itu, bagian ini juga disertai dengan contoh seperti berikut ini.

Misalnya:

Buku Pengantar Ling/g/uistik karya Verhaar dicetak beberapa kali.

Asmara/n/dana merupakan salah satu tembang macapat budaya Jawa.

Dia sedang menyelesaikan /h/utangnya di bank.

18. Pada bagian tentang penulisan unsur serapan terdapat penambahan atau pendetailan banyak unsur serapan dari bahasa Arab (berikut huruf Arabnya). 


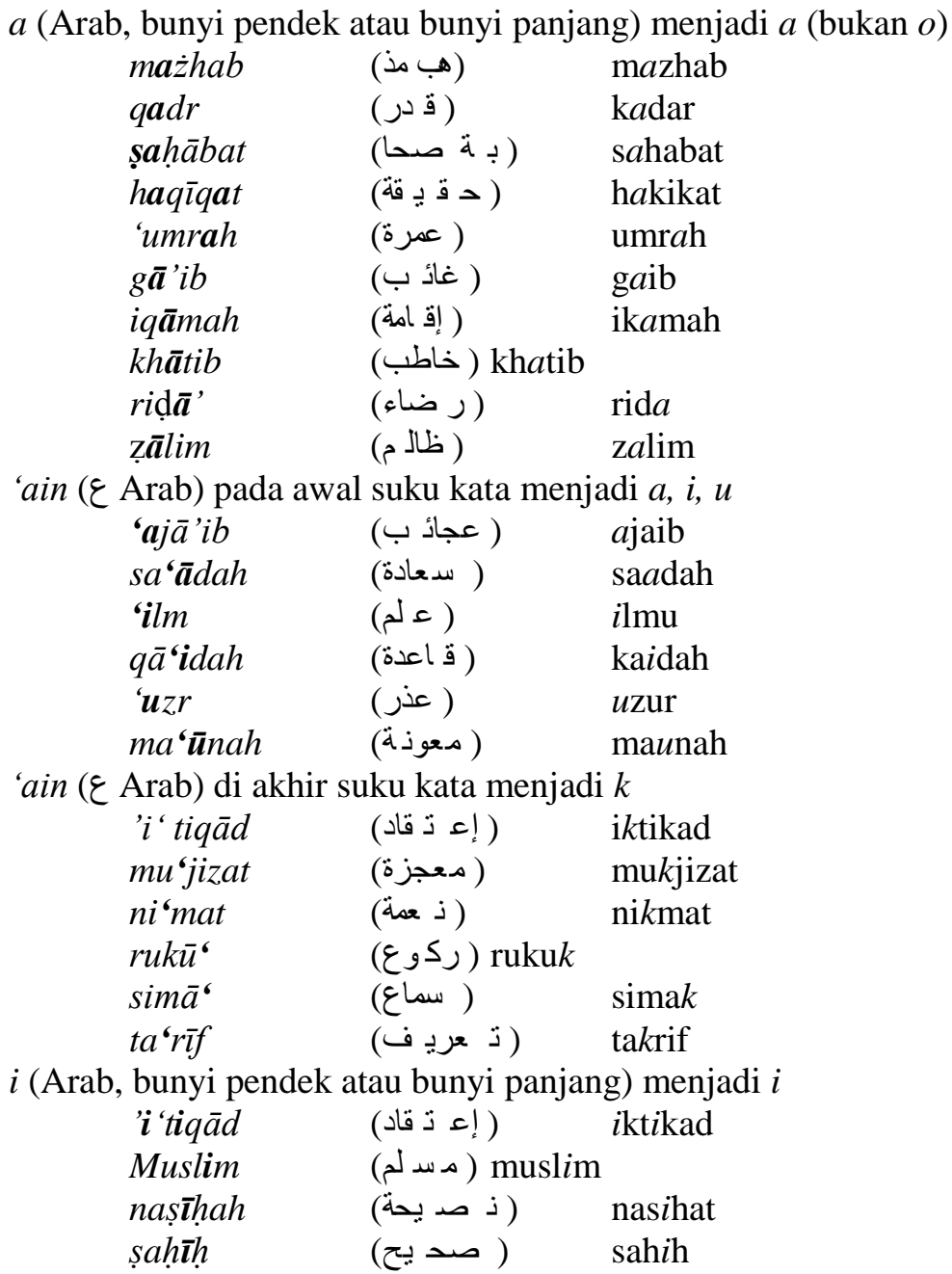

\section{Simpulan dan Saran \\ Simpulan}

Berdasarkan perbandingan kedua ejaan tersebut, dapat disimpulkan bahwa antara EYD dan PUEBI terdapat banyak sekali perubahan. Perubahan itu bisa berupa penambahan, penghilangan, pengubahan, dan pemindahan klausul. Adapun jumlah perubahan tersebut ialah 20 penambahan, 10 penghilangan, 4 pengubahan, dan 2 pemindahan.

Terdapat 20 penambahan klausul:

1) Penambahan informasi pelafaan penggunaan diakritik é dan è.

2) Penambahan keterangan: Huruf $x$ pada posisi awal kata diucapkan $[\mathrm{s}]$.

3) Penambahan diftong "ei", misalnya pada kata "survei".

4) Penambahan penjelasan unsur nama orang, yaitu yang termasuk julukan ditulis dengan huruf kapital, misalnya: Jenderal Kancil dan Dewa Pedang.

5) Penambahan penjelasan unsur nama orang yang bermakna 'anak dari' (seperti bin, binti, boru, dan van) tidak ditulis dengan huruf kapital.

6) Penambahan cara pembedaan unsur nama geografi yang menjadi bagian nama diri dan nama jenis.

7) Penambahan contoh gelar lokal, misalnya daeng, datuk, dan tubagus.

8) Penambahan penjelasan penulisan kata atau ungkapan lain yang digunakan sebagai penyapaan ditulis dengan huruf kapital, misalnya: "Hai, Kutu Buku, sedang menulis apa?"

9) Penambahan catatan bahwa nama diri dalam bahasa daerah atau bahasa asing tidak perlu ditulis dengan huruf miring. 
10) Penambahan klausul "Huruf tebal dipakai untuk menegaskan bagian tulisan yang sudah ditulis dengan huruf miring".

11) Penambahan contoh bagian karangan yang ditulis dengan huruf tebal.

12) Penambahan catatan pada butir : Imbuhan yang diserap dari unsur asing, seperti -isme, man, -wan, atau -wi, ditulis serangkai dengan bentuk dasarnya.

13) Penambahan klausul "Singkatan nama diri dan gelar yang terdiri atas dua huruf atau lebih tidak dipenggal". Selain itu juga ditambahkan contoh dan catatan.

14) Penambahan keterangan "Partikel pun yang merupakan unsur kata penghubung ditulis serangkai" dan dilengkapi pula dengan contoh pemakaiannya dalam kalimat.

15) Penambahan klausul "Bilangan yang digunakan sebagai unsur nama geografi ditulis dengan huruf", misalnya Kelapadua, Simpanglima, dan Tigaraksa.

16) Penambahan klausul penggunaan tanda hubung antara (1) kata dengan kata ganti Tuhan, (2) huruf dan angka, dan (3) kata ganti dengan singkatan.

17) Penambahan klausul "Tanda hubung digunakan untuk menandai bentuk terikat yang menjadi objek bahasan. Misalnya: Kata pasca- berasal dari bahasa Sanskerta. Akhiran isasi pada kata betonisasi sebaiknya diubah menjadi pembetonan".

18) Penambahan klausul "Tanda petik dipakai untuk mengapit judul sajak, lagu, film, sinetron, artikel, naskah, atau bab buku yang dipakai dalam kalimat".

19) Penambahan klausul pada pemakaian garis miring miring pada PUEBI ialah "Tanda garis miring dipakai untuk mengapit huruf, kata, atau kelompok kata sebagai koreksi atau pengurangan atas kesalahan atau kelebihan di dalam naskah asli yang ditulis orang lain".

20) Penambahan atau pendetailan banyak unsur serapan dari bahasa Arab.

Terdapat 10 pengurangan/penghilangan:

1) Penghilangan keterangan: * Huruf $k$ di sini melambangkan bunyi hamzah.

2) Catatan pada bagian "Gabungan Huruf Konsonan" EYD yang menyatakan bahwa "Nama orang, badan hukum, dan nama diri yang lain ditulis sesuai dengan Ejaan Bahasa Indonesia yang Disempurnakan, kecuali jika ada pertimbangan khusus" dihilangkan.

3) Penghilangan klausul "Huruf kapital dipakai sebagai huruf pertama pada kata, seperti keterangan, catatan, dan misalnya yang didahului oleh pernyataan lengkap dan diikuti oleh paparan yang berkaitan dengan pernyataan lengkap itu.

4) Penghilangan bagian 3c, yaitu klausul "Ungkapan asing yang telah diserap ke dalam bahasa Indonesia penulisannya diperlakukan sebagai kata Indonesia.

5) Penghilangan klausul bahwa bukan huruf tebal yang dipakai untuk menegaskan, melainkan huruf miring.

6) Penghilangan klausul penggunaan huruf tebal dalam kamus.

7) Penghilangan bagian B.1.b, yaitu klausul "Imbuhan dirangkaikan dengan tanda hubung jika ditambahkan pada bentuk singkatan atau kata dasar yang bukan bahasa Indonesia.

8) Penghilangan klausul "Bentuk-bentuk terikat dari bahasa asing yang diserap ke dalam bahasa Indonesia, seperti pro, kontra, dan anti, dapat digunakan sebagai bentuk dasar.

9) Penghilangan klausul "Kata tak sebagai unsur gabungan dalam peristilahan ditulis serangkai dengan bentuk dasar yang mengikutinya, tetapi ditulis terpisah jika diikuti oleh bentuk berimbuhan.

10) Penghilangan klausul "Kata ganti itu (-ku, -mu, dan -nya) dirangkaikan dengan tanda hubung apabila digabung dengan bentuk yang berupa singkatan atau kata yang diawali dengan huruf kapital".

Terdapat 4 perubahan:

1) Perubahan "bukan bahasa Indonesia" menjadi "dalam bahasa daerah atau bahasa asing" ditulis dengan huruf miring. 
2) Pada Bag II.F. terdapat perubahan judul. Jika pada EYD, judul pada bagian ini ialah "Kata Depan di, ke, dan dari", pada PUEBI judulnya diubah menjadi "Kata Depan"

3) Perubahan klausul "Tanda hubung- dipakai untuk merangkai unsur bahasa Indonesia dengan unsur bahasa daerah atau bahasa asing" dari hanya "bahasa asing" pada EYD, misalnya "di-sowan-i.

4) Perubahan klausul "Tanda kurung mengapit angka atau huruf yang memerinci satu urutan keterangan" menjadi "Tanda kurung dipakai untuk mengapit huruf atau angka yang digunakan sebagai penanda pemerincian".

Terdapat 2 pemindahan:

1) Pemindahan bagian B.2. yaitu klausul "Jika bentuk dasarnya berupa gabungan kata, awalan atau akhiran ditulis serangkai dengan kata yang langsung mengikuti atau mendahuluinya" ke bagian D.3. (Gabungan Kata).

2) Pemindahan bagian B.3. yaitu klausul "Jika bentuk dasar yang berupa gabungan kata mendapat awalan dan akhiran sekaligus, unsur gabungan kata itu ditulis serangkai" ke bagian D.4. (Gabungan Kata).

Banyaknya perubahan tersebut memperlihatkan bahwa Badan Pengembangan dan Pembinaan Bahasa Indonesia masih terus berusaha membenahi aturan Ejaan Bahasa Indonesia karena ejaan merupakan satu aspek yang penting dalam penggunaan bahasa Indonesia yang benar.

\section{Saran}

Mengingat begitu pentingnya pemahaman ejaan dalam mendukung penggunaan bahasa Indonesia yang benar dan belum banyaknya masyarakat pengguna bahasa Indonesia yang mengetahui perubahan ini, hendaknya Badan Pengembangan dan Pembinaan Bahasa Indonesia segera melakukan sosialisasi perubahan EYD menjadi PUEBI ini. Dengan demikian, aturan baru ini dapat diketahui dan diterapkan sebagaimana mestinya.Seperti kita ketahui, aturan baru akan sia-sia tanpa sosialisasi.

Sekadar diketahui, selain mengubah sistem ejaan bahasa Indonesia dari EYD menjadi PUEBI, Badan Pengembangan dan Pembinaan Bahasa Indonesia juga mencetak Kamus Besar Bahasa Indonesia (KBBI) edisi kelima pada Oktober 2016. Dalam perilisan KBBI edisi kelima ini, Badan Bahasa mengajak masyarakat umum ikut serta menyumbangkan kosakata atau istilah yang nantinya dapat digunakan sebagai lema di kamus edisi terbaru tersebut. Sebagai masyarakat yang peduli akan bahasa Indonesia, hendaknya kita dapat menyumbang kosakata atau istilah-istilah baru melalui kbbi.kemendikbud.go.id.

\section{Daftar Pustaka}

Alek A. dan H. Achmad H. P. 2010. Bahasa Indonesia untuk Perguruan Tinggi. Jakarta: Kencana Prenada Media Group.

Peraturan Menteri Pendidikan dan Kebudayaan Republik Indonesia Nomor 50 Tahun 2015 tentang Pedoman Umum Ejaan Bahasa Indonesia.

Peraturan Menteri Pendidikan Nasional Republik Indonesia Nomor 46 Tahun 2009 tentang Pedoman Umum Ejaan Bahasa Indonesia yang Disempurnakan.

Pusat Bahasa. 2010. Kamus Besar Bahasa Indonesia. Jakarta: Balai Pustaka.

Pusat Bahasa. 2016. Kamus Besar Bahasa Indonesia IV Daring. http: //kbbi4.portalbahasa.com.

Wijayanti, Sri Hapsari, dkk. 2013. Bahasa Indonesia: Penulisan dan Penyajian Karya Ilmiah. Jakarta: PT Raja Grafindo Persada. 